\title{
Efficacy of Potassium Salts of Fatty Acids in the Management of Thrips and Whitefly on Snap Beans
}

\author{
Geoffrey Ongoya Wafula ${ }^{1}$, James W. Muthomi ${ }^{1}$, John H. Nderitu ${ }^{1} \&$ George N. Chemining'wa ${ }^{1}$ \\ ${ }^{1}$ Department of Plant Science and Crop Protection, University of Nairobi. P. O Box 29053-00625 Kangemi, \\ Nairobi, Kenya \\ Correspondence: James W. Muthomi, Department of Plant Science and Crop Protection, University of Nairobi. P. \\ O. Box 29053-00625 Kangemi, Nairobi, Kenya. Tel: 254-722-984-179. E-mail: james_wanjohi@yahoo.com
}

Received: June 18, 2017 Accepted: July 31, 2017 Online Published: August 5, 2017

doi:10.5539/sar.v6n4p45 URL: https://doi.org/10.5539/sar.v6n4p45

\begin{abstract}
Snap bean farmers mainly rely on chemical pesticides to manage insect pests but the introduction of strict maximum residue levels (MRLs) by European markets poses a challenge to the use of pesticides. This has necessitated the search for alternative pest management options that do not result in harmful residues on produce. Therefore, this study was carried out to determine the efficacy of potassium salts of fatty acids as alternative to synthetic chemicals in management of snap bean pests. Field experiments were carried out in farmers' fields in Mwea and Embu for two cropping cycles between July 2013 and January 2014. Potassium salts of fatty acids at $0.5 \%, 1 \%$ and $1.5 \%$ spray solution was compared with chemical pesticide confidor ${ }^{\circledR}$ (Imidacloprid) and farmers practice $\left[\right.$ Thunder $^{\circledR}$ (Imidacloprid + Betacyfluthrin) and Karate ${ }^{\circledR}$ (Lambda Cyhalothrin). Population of thrips, whitefly, and yield of pest damaged pods, in addition to marketable pod yield was determined. Application of potassium salts of fatty acids at $1 \%$ and $1.5 \%$ significantly $(\mathrm{P}<0.05)$ reduced white fly and thrips populations by up to $54 \%$. Weight of pest damaged pods was also significantly $(\mathrm{P}<0.05)$ reduced by up to $76 \%$ while the weight of marketable pod yield was significantly $(\mathrm{P}<0.05)$ increased by up to $112 \%$. The results demonstrated that potassium salts of fatty acids are a viable alternative to synthetic chemical pesticides thereby enabling farmers to produce with acceptable residue levels that meet market requirements.
\end{abstract}

Keywords: market access, pesticide residues, Phaseolus vulgaris L., potassium salts of fatty acids

\section{Introduction}

Snap bean (Phaseolus vulgaris L.) is grown specifically for the immature green pods primarily for export market to European Union and elite local urban markets (Infonet-Biovision, 2014). The production of snap beans, one of Kenya's most important export vegetable crops, is steadily rising (HCDA, 2014). Snap beans from Kenya are exported to United Kingdom, France, Holland, Germany, United Arab Emirates and South Africa (HCDA, 2013). Local consumption of Snap beans has also increased over the last few years, providing a domestic market (HCDA, 2013). In the year 2013, Kenya exported over 31,973 tons of snap beans valued at over US\$ 105 million (HCDA, 2014)

Snap bean production is mainly by small scale farmers and it is estimated that over 50,000 smallholder families are involved in snap bean production in Kenya contributing to the larger agricultural sector (Infonet-Biovision, 2014). The agricultural sector plays an important role in Kenya's economy contributing directly and indirectly to the countries GDP by upto 24\% and 27\% in the year 2011 (MOA, 2012). Production of snap beans in Kenya is constrained by pests which include thrips (Frankliniella spp. and Megalurotrhips sjostedti), whiteflies (Bemisia tabaci and Trialeurodes vaporariorum), bean flies (Ophiomyia spp) and aphids (Aphis fabae) (Monda et al., 2003; Nderitu et al., 2007).

In Kenya, farmers rely on insecticides to manage pests in snap beans but the introduction of maximum residue levels (MRLs) for export vegetables by European retailers poses a challenge to the use of pesticides (EU, 2013; Nderitu et al., 2009). Over-reliance on sythethic chemicals pesticides has often led to non compliance by Kenyan exporters leading losses that are passed over to farmers (Mwangi, 2013; Ndung'u, 2013). Non-compliance to the market standards has also led to enhanced scrutiny of Kenyan produce with $10 \%$ of all Kenyan bean produce being sampled (Mwangi, 2013). Farmers and exporters of fresh vegetables are as a result, incurring losses through product rejects and financial bills passed to them after the MRL tests whose average cost per sample is 
approximately US\$ 247 (Mwangi, 2013; Ndung'u, 2013). The use of pest management options that are environmentally friendly and reduce reliance on synthetic chemical pesticides would be a major step towards sustainable pest management (Nderitu et al., 2009). Alternative pest management options such as use of potassium salts of fatty acids (insecticidal soaps) can be an option to overcome this challenge (Ciancio et al., 2010). Potassium salts of fatty acid work only on direct contact with the pest by washing away the protective coat on the insect surface and penetrate the cell membrane causing disruption of its permeability causing desiccation of the insect (Dheeraj et al., 2013; Mohamad et al., 2013). Potassium salts of fatty acids work on most soft-bodied insect pests (Koppert, 2013) and have been successfully used in the management of aphids, whiteflies, scales and mealy bugs with very good efficacy (Dheeraj et al., 2013; Hollingsworth, 2005; Mohamad et al., 2013). Unlike synthetic chemical pesticides, potassium salts of fatty acids are fast acting with a quick knock down effect on the pests and break down quickly after application leaving no residues (Dheeraj et al., 2013). They are also easy to handle because of their low toxicity to humans and are, therefore, are user friendly (Dheeraj et al., 2013). As a result, potassium salts of fatty acids have no MRL or PHI requirements (Koppert, 2013). This study was undertaken to determine the efficacy of potassium salts of fatty acids in the management of snap bean pests.

\section{Materials and Methods}

\subsection{Description of Experimental Sites}

The experiments were carried out in farmers' fields in the main snap bean-producing regions of Kenya in Mwea, Kirinyaga County and Embu County. Mwea has well established irrigation infrastructure that allows year round horticultural production and falls in lower midland zone 4 (LM4). The area is semiarid with Nitosols soils and average rainfall of about $850 \mathrm{~mm}$, range of $500-1250 \mathrm{~mm}$. The temperature ranges from $15.6^{\circ} \mathrm{C}$ to $28.6^{\circ} \mathrm{C}$ with a mean of about $22^{\circ} \mathrm{C}$ (Jaetzold et al., 2009). Snap bean production has recently been introduced in Embu East district of Embu County and its production is spreading fast, therefore likely to have a high uptake of new technologies. Embu East district is located in Upper Midland 2 (UM2) agro-ecological zone with average annual precipitation of $1206 \mathrm{~mm}$ and average maximum temperature of $28.8{ }^{\circ} \mathrm{C}$ and average minimum temperature $9.6{ }^{\circ} \mathrm{C}$. Snap bean production at both sites is mainly for export and is carried out by small scale farmers organized into self-help groups within the irrigation scheme.

\subsection{Experimental Treatments, Design and Layout}

The experimental treatments consisted of three concentration of potassium salts of fatty acids (Table 1) compared with chemical pesticide confidor ${ }^{\circledR}$ (Imidacloprid) and farmers practice [Thunder ${ }^{\circledR}$ (Imidacloprid 100 $\mathrm{g} / \mathrm{L}+$ Betacyfluthrin $45 \mathrm{~g} / \mathrm{L}$ ) and Karate $^{\circledR}$ (Lambda Cyhalothrin $\left.25 \mathrm{~g} / \mathrm{kg}\right]$.

Table 1. Description of experimental materials

\begin{tabular}{|c|c|c|}
\hline Product & Active ingredient (AI) & Application rate \\
\hline Potassium salts & Potassium salts of fatty acids & $\begin{array}{l}5 \mathrm{ml} \text { per litre of water }(0.5 \%), 10 \mathrm{ml} \text { per } \\
\text { litre }(1 \%) \text { and } 15 \mathrm{ml} \text { per litre of water }(1.5 \%)\end{array}$ \\
\hline Confidor WG & Imidacloprid $700 \mathrm{~g} / \mathrm{Kg}$ & $5 \mathrm{~g}$ per 15 litres of water \\
\hline Thunder $^{(B)}$ & Imidacloprid $100 \mathrm{~g} / \mathrm{L}+$ Betacyfluthrin $45 \mathrm{~g} / \mathrm{L}$ & $10 \mathrm{ml}$ in 20 litres of water \\
\hline Karate $^{\circledR}$ & Lambda Cyhalothrin $25 \mathrm{~g} / \mathrm{kg}$ & $6.5 \mathrm{ml}$ in 20 litres of water \\
\hline
\end{tabular}

Snap beans variety Serengeti were grown under irrigation over two crop cycles in July to October 2013 and October 2013 to January 2014. The experimental plots were $3 \mathrm{~m}$ by $2 \mathrm{~m}$ with $1 \mathrm{~m}$ alleys between the plots and $1.5 \mathrm{~m}$ alleys between the blocks and each treatment was replicated four times. The crop was planted in single rows with spacing of $10 \mathrm{~cm} \times 30 \mathrm{~cm}$. The experiment was laid out in a randomized complete block design. Fertilizer application was done once at planting using di-ammonium phosphate $\left(18 \% \mathrm{~N}\right.$ and $\left.46 \% \mathrm{P}_{2} \mathrm{O}_{5}\right)$ at the rate of $490 \mathrm{~kg}$ per ha. Top dressing was done at 21 days after emergence with calcium ammonium nitrate at the rate of $490 \mathrm{~kg}$ per ha. The first weeding was done two weeks after emergence (WAE) followed by a second weeding two weeks later. Diseases were controlled using Kocide ${ }^{\circledR}$ (Copper Hydroxide 61.4\%) for rust and rots, Oshothane $^{\circledR}$ (Mancozeb) against leaf spots and Ortiva ${ }^{\circledR}$ (Azoxystrobin 250g/L) against mildews. The experimental treatments were applied as follows:

i. $\quad 0.5 \%$ potassium salts applied weekly from 3 weeks after emergence until early pod formation

ii. $1 \%$ potassium salts applied weekly from 3 weeks after emergence until early pod formation

iii. $\quad 1.5 \%$ potassium salts applied weekly from 3 weeks after emergence until early pod formation

iv. $\quad$ Chemical pesticide confidor ${ }^{\circledR}$ (Imidacloprid) applied every two weeks 


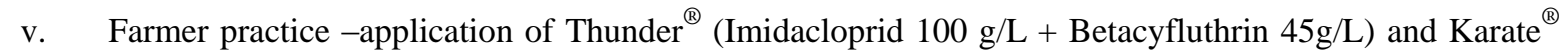
(Lambda Cyhalothrin $25 \mathrm{~g} / \mathrm{kg}$ ) on pest detection

vi. Control - spray with water only

\subsection{Assessment of Whitefly and Thrips Population}

Population of whiteflies was assessed using yellow sticky trap counts for adults and leaf counts for nymphs. A yellow sticky trap was placed at the centre of each plot and the number of adult whitefly was counted bi-weekly (Hirano et al.,1995; Hoelmer et al., 1998) at two, four, six and eight weeks after emergence (WAE). The number of whitefly nymphs was counted bi-weekly at two, four, six and eight WAE by sampling ten lower leaves from ten plants in a zig-zag manner from inner rows of each plot (Soto et al., 2002).

Population of thrips was assessed weekly from the start of flowering on ten flowers sampled from ten plants from the inner rows in each plot. Sampling was done three times at six, seven and eight weeks after emergence. The sampled flowers were immediately put in $70 \%$ ethanol until the insects were counted in the laboratory. Each flower was placed in a petri dish, dissected and the thrips washed into the ethanol. The thrips were observed under a dissecting microscope and counted using a tally counter. Both adults and larvae thrips stages were counted and identified based on morphological characteristics (Nderitu, et al., 2009).

\subsection{Assessment of Pod Yield and Quality}

Harvesting and grading of pods was done twice every week for two weeks. The pods were harvested from three inner rows in each plot and graded into marketable and non-marketable yields. The marketable pods were further graded into extra-fine (6 to $7.5 \mathrm{~mm}$ in diameter and 8 to $12 \mathrm{~cm}$ long) and fine $(6.5$ to $9 \mathrm{~mm}$ in diameter and 10 to $13 \mathrm{~cm}$ long) according to USAID-KHCP (2011). The non-marketable pods were further graded into pest damaged pods and other rejects based on pest damage symptoms such as feeding marks, scarring and malformation (Infonet-Biovision, 2013). The weight of the each grade of the harvested pods for each plot was recorded.

\subsection{Cost Benefit Analysis of the Pest Management Options}

Net return was calculated as the total of the entire marketable yield for each treatment multiply by the average price per kilogram minus the total costs while the cost benefit ratio was calculated by dividing the total cost by the net return as follows:

Total marketable pod yield $=$ Total extra-fine + Total fine

$$
\text { Average Price }=\frac{\text { Price for extra-fine }+ \text { Price for fine }}{2}
$$

Total cost $=$ Land preparation cost + Labour + Cost of inputs

Gross returns $=$ Total marketable $\mathrm{x}$ Average price

Net returns $=$ Gross returns - Total cost

$$
\text { Cost benefit ration }=\frac{\text { Total Cost }}{\text { Net Returns }}
$$

\subsection{Statistical Data Analysis}

Analysis of variance (ANOVA) was carried out on the data from the two seasons using GenStat Edition 13 software and tested for significance by F-test at $95 \%$ level. The treatment means were then compared using the least significant difference (LSD) test at $\mathrm{P}=0.05$ where the F-test was significant (Mead et al., 2003).

\section{Results}

Potassium salts of fatty acids at rate of $1 \%$ and $1.5 \%$ significantly $(\mathrm{P}<0.05)$ reduced both adult and nymph whitefly population compared to untreated plots. Similar results were observed for the number of thrips per flower. Application of potassium salts of fatty acids at $1.5 \%$ compared well with confidor $^{\circledR}$ (Imidacloprid) in reducing white fly and thrips population but the application of application of Thunder ${ }^{\circledR}$ (Imidacloprid + Betacyfluthrin) followed by Karate ${ }^{\circledR}$ (Lambda Cyhalothrin) was less effective (Figure 1). The application of potassium salts of fatty acids at $1.5 \%$ and confidor ${ }^{\circledR}$ (Imidacloprid) resulted in the least amount of pest damaged pods. 

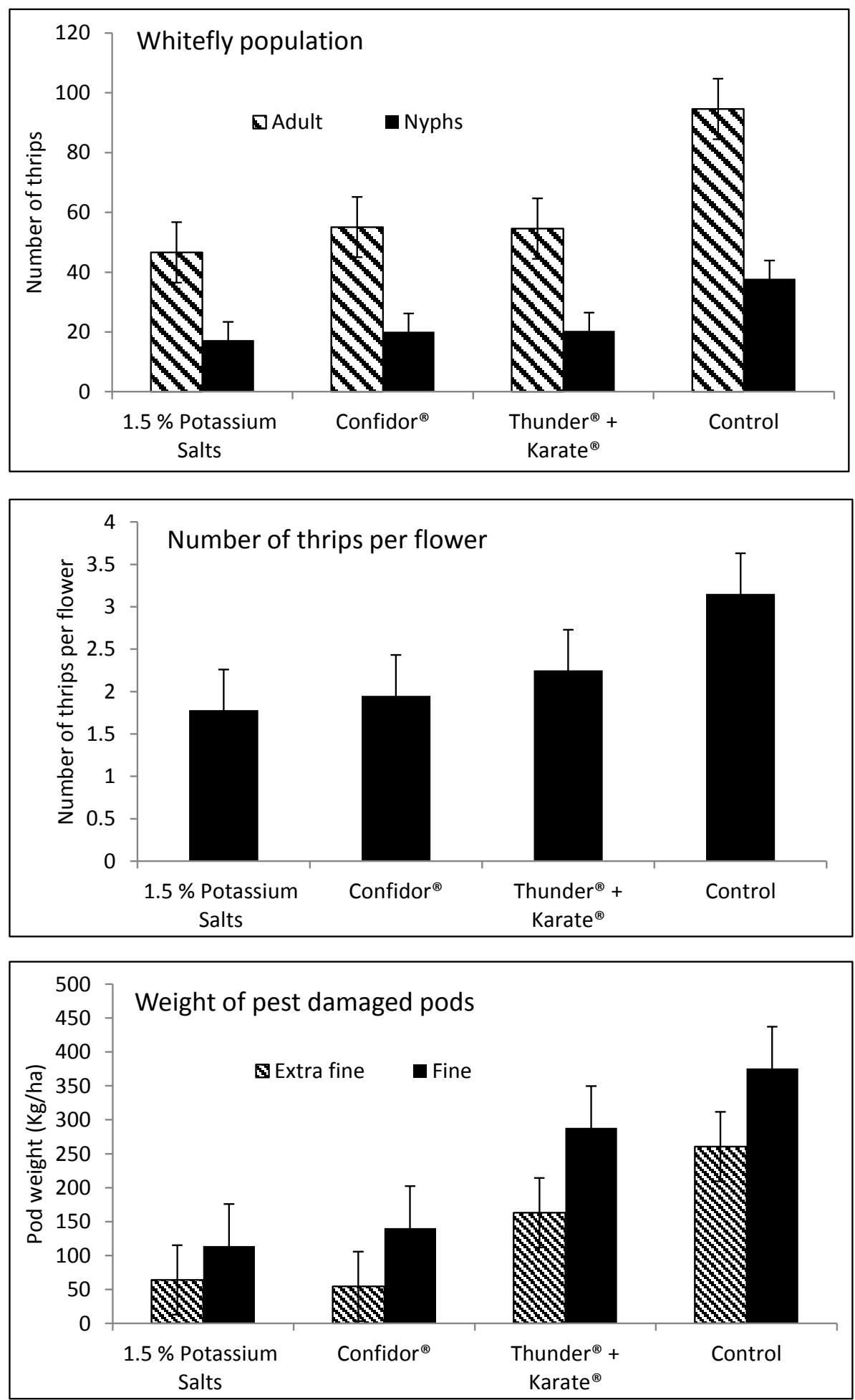

Figure 1. Population of whitefly and thrips and pod weight of pest damaged snap bean pods after application of potassium salts of fatty acid as compared to pesticides Confidor ${ }^{\circledR}$ (Imidacloprid) and Thunder $^{\circledR}$ (Imidacloprid + Betacyfluthrin) followed by Karate ${ }^{\circledR}$ (Lambda Cyhalothrin)

There was a general reduction in whitefly population with increase in concentration potassium salts of fatty acids in all the treated plots compared to plots without treatment. (Tables 2). Potassium salts of fatty acids at $1 \%$ and $1.5 \%$ had the highest reduction of up to $50 \%$ and $54 \%$ in adult and nymph whitefly population. Application of 
confidor $^{\circledR}$ (Imidacloprid) and Thunder $^{\circledR}$ (Imidacloprid + Betacyfluthrin) followed by Karate $^{\circledR}$ (Lambda Cyhalothrin) reduced the whitefly population by up to $47 \%$ and $46 \%$, respectively. No whitefly incidence was recorded in Embu during the first and second season. Application of potassium salts of fatty acids at $1 \%$ and $1.5 \%$ significantly $(\mathrm{P}<0.05)$ reduced the thrips population at both Embu and Mwea site by up to $58 \%$ and their activity was comparable to the application of chemicals Confidor ${ }^{\circledR}$ and Thunder $^{\circledR}$ followed by Karate ${ }^{\circledR}$ (Table 3). The level of thrips population per flower was higher in Mwea than in Embu.

Potassium salts of fatty acids at the rate of $1 \%$ and $1.5 \%$ resulted in the highest and significant $(\mathrm{P}<0.05)$ increase of extra-fine and fine pods by up to $112 \%$ and $46 \%$, respectively, in Mwea (Table 4). However, in Embu, the application of both potassium salts of fatty acids and chemicals did not have any significant (P-value >0.05) effect on the yield of both extra-fine and fine pods during the first season and second season (Table 4.0). Potassium salts of fatty acids significantly $(\mathrm{P}<0.05)$ reduced pest damaged extra-fine and fine pods (Table 5.0). Potassium salts of fatty acids at the rate $1.5 \%$ and chemical treatment with confidor ${ }^{\circledR}$ potassium salts spray solution had the highest reduction of pest damage in both the extra-fine and fine grade of $76 \%$ and $69 \%$ respectively in Mwea (Table 5). In Embu, potassium salts of fatty acids had significant $(\mathrm{P}<0.05)$ effect on the pest damaged pods. Potassium salts of fatty acids at the rate of $1.5 \%$ potassium salts and chemical treatment with confidor ${ }^{\circledR}$ had the highest reduction of $70 \%$ and $58 \%$ reduction respectively in pest damaged fine pods (Table 5). The use of potassium salts at $1 \%$ and $1.5 \%$ had the least cost-benefit ratio, followed by Confidor ${ }^{\circledR}$ (imidachloprid) (Figure 2). The least profitable pest management options were potassium salts at $0.5 \%$ and in plots with application of Thunder ${ }^{\circledR}$ (Imidacloprid + Betacyfluthrin) followed by Karate ${ }^{\circledR}$ (Lambda Cyhalothrin) which was comparable to control plots.

Table 2. Mean number adult whitefly per sticky card and whitefly nymphs per leaf for different rates of potassium salts per season in snap beans in Mwea

\begin{tabular}{|c|c|c|c|c|c|c|}
\hline & \multicolumn{3}{|c|}{ Adult whitefly } & \multicolumn{3}{|c|}{ Whitefly nymphs } \\
\hline Treatments & Season 1 & Season 2 & Mean & Season 1 & Season 2 & Mean \\
\hline $0.5 \%$ Potassium salts & $92.0 \mathrm{c}$ & $68.7 \mathrm{~b}$ & $80.3 \mathrm{~b}$ & $32.5 \mathrm{bc}$ & $34.9 \mathrm{~b}$ & $33.4 \mathrm{~b}$ \\
\hline $1 \%$ Potassium Salts & $68.4 \mathrm{ab}$ & $33.4 \mathrm{a}$ & $50.9 \mathrm{a}$ & $30.5 b$ & $17.3 \mathrm{a}$ & $18.9 \mathrm{a}$ \\
\hline $1.5 \%$ Potassium Salts & $62.6 \mathrm{a}$ & $30.7 \mathrm{a}$ & 46.6a & $19.9 \mathrm{a}$ & $14.9 \mathrm{a}$ & $17.3 \mathrm{a}$ \\
\hline Confidor $^{(}$ & $82.4 \mathrm{bc}$ & $27.9 \mathrm{a}$ & $55.1 \mathrm{a}$ & $21.6 \mathrm{a}$ & $18.5 \mathrm{a}$ & $20.1 \mathrm{a}$ \\
\hline Thunder $^{\circledR}+$ Karate $^{\circledR}$ & $76.6 \mathrm{~b}$ & $33.4 \mathrm{a}$ & $54.6 \mathrm{a}$ & $21.2 \mathrm{a}$ & $20.0 \mathrm{a}$ & $20.4 \mathrm{a}$ \\
\hline Control (Water only) & $110.9 \mathrm{~d}$ & $78.7 \mathrm{~b}$ & $94.6 \mathrm{c}$ & $37.1 \mathrm{c}$ & $38.7 \mathrm{~b}$ & $37.8 \mathrm{~b}$ \\
\hline $\operatorname{LSD}\left({ }_{\mathrm{p} \leq 0.05}\right)$ & 13.6 & 16.4 & 10.1 & 5.4 & 9.7 & 6.1 \\
\hline C.V\% & 1.7 & 8.4 & 3.9 & 8.4 & 11.9 & 10.0 \\
\hline
\end{tabular}

Treatments with different letters in the same column are significantly different at $5 \%$ probability

Table 3. Mean number thrips per flower for different rates of potassium salts per season in snap beans in Mwea and Embu

\begin{tabular}{|c|c|c|c|c|c|c|}
\hline & Mwea & & & Embu & & \\
\hline Treatments & Season 1 & Season 2 & Mean & Season 1 & Season 2 & Mean \\
\hline $0.5 \%$ Potassium salts & $2.90 \mathrm{~b}$ & $2.40 \mathrm{~cd}$ & $2.65 b$ & $0.33 b$ & $1.70 b c$ & $1.00 \mathrm{bc}$ \\
\hline $1 \%$ Potassium Salts & $2.00 \mathrm{a}$ & $1.70 \mathrm{ab}$ & $1.85 \mathrm{ab}$ & $0.27 \mathrm{ab}$ & $0.93 \mathrm{a}$ & $0.60 \mathrm{ab}$ \\
\hline $1.5 \%$ Potassium Salts & $1.90 \mathrm{a}$ & $1.60 \mathrm{a}$ & $1.78 \mathrm{a}$ & $0.18 \mathrm{a}$ & $0.79 \mathrm{a}$ & $0.49 \mathrm{a}$ \\
\hline Confidor $^{\circledR}$ & $2.10 \mathrm{a}$ & $1.80 \mathrm{ab}$ & $1.95 \mathrm{ab}$ & $0.17 \mathrm{a}$ & $0.88 \mathrm{a}$ & $0.53 \mathrm{ab}$ \\
\hline Thunder $^{\circledR}+$ Karate $^{\circledR}$ & $2.30 \mathrm{ab}$ & $2.20 \mathrm{bc}$ & $2.25 \mathrm{ab}$ & $0.29 b$ & $1.27 \mathrm{ab}$ & $0.78 b$ \\
\hline Control (Water only) & $3.60 \mathrm{c}$ & $2.70 \mathrm{~d}$ & $3.15 \mathrm{c}$ & $0.35 b$ & $1.97 \mathrm{c}$ & $1.16 \mathrm{c}$ \\
\hline $\operatorname{LSD}(p \leq 0.05)$ & 0.60 & 0.56 & 0.48 & 0.11 & 0.50 & 0.26 \\
\hline C.V\% & 15.80 & 3.20 & 13.2 & 14.40 & 8.80 & 9.70 \\
\hline
\end{tabular}

Treatments with different letters in the same column are significantly different at $5 \%$ probability 
Table 4. Total yield $(\mathrm{kg} / \mathrm{ha})$ of marketable snap bean pods in each grade for different rates of potassium salts in snap beans per season plantings in Mwea and Embu

\begin{tabular}{|c|c|c|c|c|c|c|}
\hline & \multicolumn{3}{|c|}{ Extra fine pods } & \multicolumn{3}{|l|}{ Fine pods } \\
\hline & Season 1 & Season 2 & Mean & Season 1 & Season 2 & Mean \\
\hline \multicolumn{7}{|l|}{ Mwea } \\
\hline $0.5 \%$ Potassium salts & 2394ab & $1529 a$ & $1962 \mathrm{a}$ & $2654 a$ & $5679 b c$ & $4166 \mathrm{~b}$ \\
\hline $1 \%$ Potassium Salts & $2760 \mathrm{bc}$ & $3049 \mathrm{c}$ & $2905 b$ & $2754 a$ & $6055 c$ & $4404 b$ \\
\hline $1.5 \%$ Potassium Salts & $4072 \mathrm{~cd}$ & $3236 c$ & $3654 b$ & $2754 a$ & $5706 c$ & $4230 \mathrm{~b}$ \\
\hline Confidor $^{\circledR}$ & $3138 \mathrm{c}$ & $3099 \mathrm{c}$ & $3118 b$ & $2974 a$ & $5658 \mathrm{bc}$ & $4316 b$ \\
\hline Thunder $^{\circledR}+$ Karate $^{\circledR}$ & $3748 \mathrm{c}$ & $2355 \mathrm{abc}$ & $3050 \mathrm{~b}$ & $3898 \mathrm{a}$ & $4180 \mathrm{ab}$ & $4039 b$ \\
\hline Control (Water only) & $1624 a$ & $1821 \mathrm{ab}$ & $1722 a$ & $1946 a$ & $4092 a$ & $3019 a$ \\
\hline $\operatorname{LSD}(p \leq 0.05)$ & 1052 & 1203 & 943 & 1624 & 1509 & 947 \\
\hline C.V\% & 15 & 13 & 11.5 & 30.1 & 16.8 & 5.5 \\
\hline \multicolumn{7}{|l|}{ Embu } \\
\hline $0.5 \%$ Potassium salts & $5826 \mathrm{a}$ & $1165 \mathrm{a}$ & $3496 a$ & $6621 a$ & $1324 a$ & $3973 a$ \\
\hline $1 \%$ Potassium Salts & $7090 \mathrm{a}$ & $1418 \mathrm{a}$ & $4254 a$ & $6068 \mathrm{a}$ & $1214 \mathrm{a}$ & $3640 \mathrm{a}$ \\
\hline $1.5 \%$ Potassium Salts & $7386 a$ & $1477 \mathrm{a}$ & $4432 \mathrm{a}$ & $5801 \mathrm{a}$ & $1160 \mathrm{a}$ & $3481 \mathrm{a}$ \\
\hline Confidor $^{\circledR}$ & $5936 a$ & $1187 \mathrm{a}$ & $3562 \mathrm{a}$ & $6271 \mathrm{a}$ & $1254 \mathrm{a}$ & $3763 a$ \\
\hline Thunder $^{\circledR}+$ Karate $^{\circledR}$ & $6085 a$ & $1217 \mathrm{a}$ & $3651 \mathrm{a}$ & $5976 a$ & $1195 \mathrm{a}$ & $3586 a$ \\
\hline Control (Water only) & $5510 \mathrm{a}$ & $1102 a$ & $3306 a$ & $4043 a$ & $847 a$ & $2445 \mathrm{a}$ \\
\hline $\operatorname{LSD}(p \leq 0.05)$ & 2564 & 513 & 1538 & 1983 & 421 & 1201 \\
\hline C.V\% & 12.7 & 12.7 & 12.7 & 12.4 & 12.5 & 12.4 \\
\hline
\end{tabular}

Treatments with different letters in the same column are significantly different at $5 \%$ probability

Table 5. Total yield (kg/ ha) of pest damaged snap bean pods in each grade for different rates of potassium salts in snap beans per season plantings in Mwea and Embu

\begin{tabular}{|c|c|c|c|c|c|c|}
\hline & \multicolumn{3}{|c|}{ Extra fine pods } & \multicolumn{3}{|l|}{ Fine pods } \\
\hline & Season 1 & Season 2 & Mean & Season 1 & Season 2 & Mean \\
\hline \multicolumn{7}{|l|}{ Mwea } \\
\hline $0.5 \%$ Potassium salts & $149 \mathrm{~b}$ & $66 a$ & $108 \mathrm{~b}$ & $224 a b$ & $265 b$ & $244 b$ \\
\hline $1 \%$ Potassium Salts & $128 \mathrm{ab}$ & $69 \mathrm{a}$ & $98 \mathrm{ab}$ & $187 \mathrm{a}$ & $114 \mathrm{a}$ & $150 \mathrm{a}$ \\
\hline $1.5 \%$ Potassium Salts & $90 \mathrm{a}$ & $28 \mathrm{a}$ & $59 \mathrm{a}$ & $164 \mathrm{a}$ & $79 \mathrm{a}$ & $121 \mathrm{a}$ \\
\hline Confidor $^{\circledR}$ & $72 a$ & $98 \mathrm{a}$ & $85 \mathrm{ab}$ & $156 \mathrm{a}$ & $110 \mathrm{a}$ & $133 \mathrm{a}$ \\
\hline Thunder $^{\circledR}+$ Karate $^{\circledR}$ & $203 c$ & $103 a$ & $153 \mathrm{c}$ & $274 \mathrm{bc}$ & $328 b$ & $301 b$ \\
\hline Control (Water only) & $221 \mathrm{c}$ & $274 b$ & $247 \mathrm{~d}$ & $328 \mathrm{c}$ & $465 c$ & $396 \mathrm{c}$ \\
\hline $\operatorname{LSD}(p \leq 0.05)$ & 57 & 89 & 41 & 70 & 106 & 63 \\
\hline C.V\% & 11.6 & 24.8 & 13.3 & 28.4 & 10.0 & 16.7 \\
\hline \multicolumn{7}{|l|}{ Embu } \\
\hline $0.5 \%$ Potassium salts & $234 \mathrm{~b}$ & $91 \mathrm{c}$ & $163 \mathrm{~b}$ & $389 \mathrm{~b}$ & $78 \mathrm{~b}$ & $233 b$ \\
\hline $1 \%$ Potassium Salts & $84 \mathrm{a}$ & $47 \mathrm{~b}$ & $66 \mathrm{a}$ & $268 \mathrm{a}$ & $54 \mathrm{a}$ & $161 \mathrm{a}$ \\
\hline $1.5 \%$ Potassium Salts & $115 \mathrm{a}$ & $23 \mathrm{a}$ & $69 \mathrm{a}$ & $178 \mathrm{a}$ & $36 \mathrm{a}$ & $107 \mathrm{a}$ \\
\hline Confidor $^{\circledR}$ & $39 a$ & $8 \mathrm{a}$ & $24 \mathrm{a}$ & $246 \mathrm{a}$ & $49 a$ & $148 \mathrm{a}$ \\
\hline Thunder $^{\circledR}+$ Karate $^{\circledR}$ & $288 b$ & $59 \mathrm{~b}$ & $173 b$ & $459 \mathrm{~b}$ & $92 b$ & $275 b$ \\
\hline Control (Water only) & $456 c$ & $91 \mathrm{c}$ & $274 \mathrm{c}$ & $592 \mathrm{c}$ & $119 \mathrm{c}$ & $355 \mathrm{c}$ \\
\hline $\operatorname{LSD}(\mathrm{p} \leq 0.05)$ & 101 & 20 & 61.2 & 100 & 20 & 60.4 \\
\hline C.V\% & 24.1 & 24.1 & 24.1 & 18.9 & 18.9 & 18.9 \\
\hline
\end{tabular}

Treatments with different letters in the same column are significantly different at $5 \%$ probability 


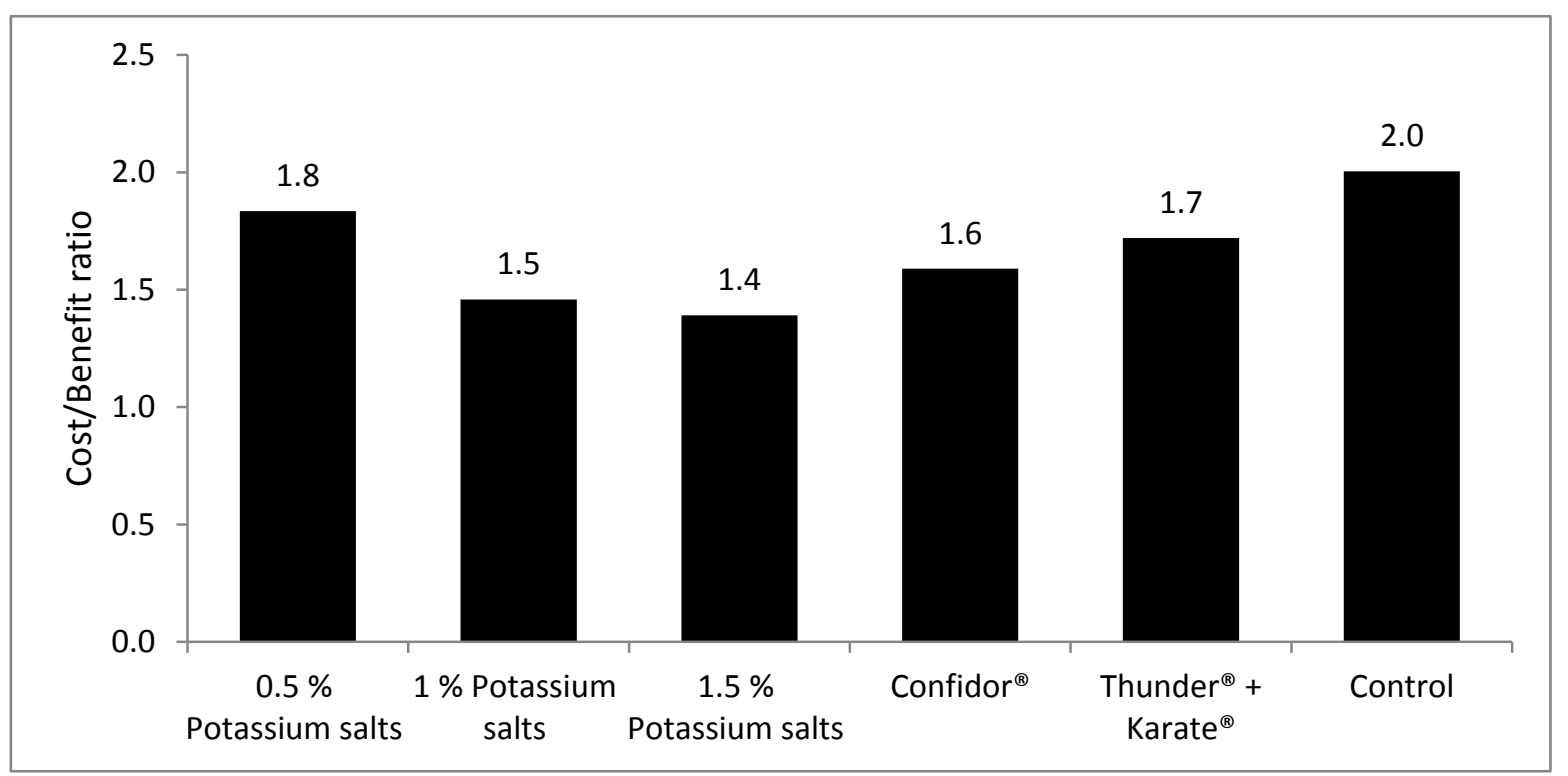

Figure 2. Cost-benefit ratios for potassium salts of fatty acids and conventional chemicals in management of white fly and thrips in snap beans

\section{Discussion}

Potassium salts of fatty acids at $1.5 \%$ concentration significantly $(\mathrm{P}<0.05)$ reduced whitefly population and was effective in the management of whitefly causing up to $65 \%$ reduction in whitefly population. However, potassium salts at $0.5 \%$ had no significant $(\mathrm{P}>0.05)$ effect compared to the untreated control plots. These findings are consistent with reports by Mohamad et al., (2013) and Dheeraj et al., (2013) who the reported effect of potassium salts on aphids and whiteflies, respectively. Similar results have been reported by Liu et al., (2000), Vavrina et al., (1995) and Ciancio et al., (2010). Hollingsworth, (2005) also reported the control of scales and mealybugs using potassium salts of fatty acids.

The effectiveness of potassium salts of fatty acids this study increased with the increase in their concentration in the spray solution. The results agree with the findings by Liu et al., (2000) where increase in the concentration of potassium salts resulted in higher mortalities in whitefly. These results demontrated that potassium salts are just as effective as synthetic chemical pesticides in the management of whitefly (Dheeraj et al., 2013).

Potassium salts of fatty acids work only on direct contact with the pest (Liu et al., 2000) and work on most soft-bodied insect pests (Koppert, 2013). They have been successfully used in the management of aphids, whiteflies, scales and mealy bugs (Mohamad et al., 2013; Dheeraj et al., 2013; Hollingsworth, 2005).

The results of this study showed that potassium salts of fatty acids at $1.5 \%$ concentration were also effective in management of thrips causing up to $68 \%$ reduction in their population. The results are consistent with the findings by Clinton et al., (2011) who reported the management of thrips in onions and by Heidi and Cullen (2008), Ciancio et al. (2010), Mohamad et al. (2013) and Dheeraj et al. (2013) on aphids and other arthropod pests. Potassium salts of fatty acids wash away the protective coating on the insect surface and penetrate the cell membrane causing disruption of the cell membrane permeability which leads to desiccation of the insects (Mohamad et al., 2013; Dheeraj et al., 2013; Ciancio et al., 2010).

Snap bean pod yield was significantly ( $\mathrm{P}>0.05)$ increased by up to $151 \%$ by application of $1 \%$ and $1.5 \%$ potassium salts of fatty acids and the yield increase was comparable to that obtained from the plots treated with conventional chemicals confidor $^{\circledR}$ (Imidacloprid) and Thunder $^{\circledR}$ (Imidacloprid + Betacyfluthrin) followed by Karate $^{\circledR}$ (Lambda Cyhalothrin). The results concur with findings by Clinton et al., (2011) who reported an increase in yield with decrease in pest population after application of potassium salts of fatty acids and by Nderitu et al., (2009), Delkhoshi et al., (2012) and El-Mohamedy et al., (2008) as a result of application of pest control measures to reduce pest populations. However, the results of the current study contradicts the results by Vavrina et al., (1995) who reported that application of higher rates of potassium salts of fatty acids reduced yield of tomato fruits due to reduced biomass as a result of phytotoxicity at higher concentrations of potassium salts of 
fatty acids.

The study showed that potassium salts of fatty acids are as effective as synthetic chemicals in managing pests in snap bean production resulting in increased yields and produce quality as reported by Dheeraj et al. (2013) and Mohamad et al. (2013). However, unlike synthetic chemical pesticides, potassium salts of fatty acids are fast acting with a quick knock down effect on the pests and break down quickly after application leaving no residues on the crop (Dheeraj et al., 2013; Hollingsworth, 2005). The cost benefit analysis showed that the use of potassium salts for management of thrips and whitefly was just as profitable as using the chemical pesticides. Potassium salts at $1.5 \%$ concentration was most effective and more profitable compared to concentrations of $0.5 \%$ and $1.5 \%$. Though the potassium salts were as equally effective as synthetic chemicals, they pose no risk of residues on the crop and therefore offer the best alternative to chemical pesticides.

The results above demonstrate that potassium salts of fatty acids at the concentration of $1.5 \%$ potassium salts in spray solution are effective in the management of thrips and whiteflies on snap beans and can be used as alternative to synthetic chemical pesticides in snap bean production. Snap bean farmers depend on continuous and excessive use of synthetic pesticides often leading to accumulation of hazardous residues, development of resistant pest strains and loss of biodiversity due to toxicity to non-target organisms, in addition to the direct negative effect on health of the producers (Cardona et al., 2012; Das et al., 2010; Gorman et al., 2007; Kumar et al., 2012). High residue levels in fresh vegetables is the common cause of non-compliance to European market standards thus leading to enhanced scrutiny of Kenyan produce at the market with $10 \%$ of all Kenyan bean produce being sampled (Mwangi, 2013). Potassium salts of fatty acids are fast acting, break down quickly after application leaving no residues and are easy to handle because of their low toxicity to humans (Dheeraj et al., 2013). Therefore, they have no MRL or PHI requirements (Koppert, 2013) thus they would enable snap bean produce meet the stringent European market thereby reducing the losses currently experienced by fresh vegetable farmers and exporters (Mwangi, 2013; Ndung'u, 2013).

\section{Acknowledgement}

The authors wish to thank the Kenya Agricultural Productivity and Agribusiness Project (KAPAP) for funding this study under the Grant Number KAPAP/comp.2/06/Vol.II/39 and Koppert Biological Systems (K) for providing logistical support.

\section{References}

Cardona, C., Frei, A., Bueno, J. M., Diaz, J., Gu, H., \& Dorn, S. (2012). Resistance to Thrips palmi (Thysanoptera: Thripidae) in Bean. Journal of Economic Entomology, 95(5), 1066-1073. https://doi.org/10.1603/0022-0493-95.5.1066.

Ciancio, A., \& Mukerji, K. G. (2010). Integrated management of arthropod pests and insect borne diseases. Springer science + Business BV, London New York. https://doi.org/10.1007/978-90-481-8606-8

Clinton, C. S., Erik, B. G. F., Kenzie, J. B., \& Lamont, D. S. (2011). Insecticide rotations for control of thrips in onions. Ontario Malheur Experiment Station, Oregon State University.

Das, S., Roy, S., \& Mukhopadhyay, A. (2010). Diversity of arthropod natural enemies in the tea plantations of North Bengal with emphasis on their association with tea pests. Current Science, 99, 1457-1463.

Delkhoshi, H., \& Jalilian, J. (2012). Effect of pre-sowing seed treatment and spraying of bio-organic nutrient on yield and yield components of maize (Zea mays L.). International Research Journal of Applied and Basic Sciences, 3(9), 1867-1873.

Dheeraj, J., Susan, V. P., \& Nisha, S. (2013). Fatty acid metallic salts and pyrethroids - environmental friendly pesticides. International Journal of Scientific Research and Reviews, 2(1), 43- 51.

El-Mohamedy, R. S. R., \& Abd El-Baky, M. M. H. (2008). Evaluation of different types of Seed Treatment on Control of Root Rot Disease, Improvement Growth and Yield Quality of Pea Plant in Nobaria Province. Research Journal of Agriculture and Biological Sciences, 4(6), 611-622.

European Union (EU) (2013). Maximum residue levels (MRLs) for pesticides in food. www.cbi.eu. Accessed $20^{\text {th }}$ March 2014.

Fritz, L. L., Heinrichs, E. A., Machado, V., Andreis, T. F., Pandolfo, M., de Salles, S. M., de Oliveira, J. V., \& Fiuza, L. M. (2013). Impact of lambdacyhalothrin on arthropod natural enemy populations in irrigated rice fields in southern Brazil. International Journal of Tropical Insect Science, 33(3), 178-187.

https://doi.org/10.1017/S1742758413000192. 
Gorman, K., Devine, D., Bennison, J., Coussons, P., Punchard, N., \& Denholm, I. (2007). Report of resistance to the neonicotinoid insecticide imidacloprid in Trialeurodes vaporariorum (Hemiptera: Aleyrodidae). Pest Management Science, 63, 555-558. https://doi.org/10.1002/ps.1364

Heidi, K., \& Cullen, E. M. (2008). Efficacy and nontarget effects of reduced-risk insecticides on Aphis glycines Hemiptera: Aphididae) and its biological control agent Harmonia axyridis (Coleoptera: Coccinellidae). Journal of Economic Entomology, 101, 2391- 398.

Hirano, K., Budiyanto, E., Swastika, N., \& Fujii, K. (1995). Population dynamics of the whitefly, Bemisia tabaci (Gennadius) (Homoptera: Aleyrodidae), in Java, Indonesia, with special reference to spatio-temporalchanges in the quantity of food resources. Ecological Research, 1(1), 75-85. https://doi.org/10.1007/BF02347657.

Hoelmer, K. A., Roltsch, V. J., Chu, E. C., \& Hekneberry, T. J. (1998). Selectivity of Whitefly Traps in Cotton for Eretmocerus eremicus(Hymenoptera: Aphelinidae), a Native Parasitoid of Bemisia argentifolii (Homoptera: Aleyrodidae). Environmental Entomology, 27(4), 1039-1044. https://doi.org/10.1093/ee/27.4.1039

Hollingsworth, R. G. (2005). Limonene, a citrus Extract, for control of mealybugs and scale insects. Journal of Economic Entomology, 98(3), 772-779. https://doi.org/10.1603/0022-0493-98.3.772

Horticultural Crop Development Authority (HCDA) (2013). Export statistics for horticultural crops in 2012. Horticultural Crop Development Authority, Nairobi, Kenya.

Horticultural Crop Development Authority (HCDA) (2014). Vegetables- French Beans. http://www.hcda.or.ke/?page_id=10541. Accessed 16 $6^{\text {th }}$ May 2014.

Infonet-Biovision (2013). Infonet-Biovision. http://www.infonet-biovision.org/default/ct/118/crops. Accessed $6^{\text {th }}$ July 2013

Infonet-Biovision (2014). Infonet-Biovision. http://www.infonet-biovision.org/default/ct/118/crops. Accessed $16^{\text {th }}$ May 2014.

Jaetzold, R., Schmidt, H., Hornetz, B., \& Shisanya, C. (2009). Farm Management Handbook of Kenya VOL. IINatural Conditions and Farm Management Information -2nd Edition. Nairobi, Kenya.

Koppert (2013). www.koppert.com: http://www.koppert.com/products/products-pests-diseases/products/detail/savona-3/. Accesed $6^{\text {th }}$ July 2013.

Kumar, R., Kranthi, S., Nitharwal, M., Jat, S. L., \& Monga, D. (2012). Influence of pesticides and application methods on pest and predatory arthropods associated with cotton. Phytoparasitica, 10(10), 12-241. https://doi.org/10.1007/s12600-012-0241-5

Liu, T., \& Stansly, P. A. (2000). Insecticidal activity of surfactants and oils against silverleaf whitefly (Bemisia argentifolii) nymphs (Homoptera: Aleyrodidae) on collards and tomato. Pest Management Science, 56, 861-866. https://doi.org/10.1002/1526-4998(200010)56:10<861::AID-PS217>3.3.CO;2-P

Mead, R., Curnow, R. N., \& Hasted, A. M. (2003). Statistical methods in qgriculture and experimental biology. Third Edition. p 122. Chapman \& Hall / CRC.

Ministry of Agriculture (2012). National Horticulture Policy. http://www.kilimo.go.ke/kilimo_docs/pdf/National_Horticulture_Policy.pdf. Accessed 16 ${ }^{\text {th }}$ May 2014.

Mohamad, S. F. S., Mohamad, S., \& Aziz, A. A. (2013). The susceptibility of aphids, Aphis gossypii Glover to lauric acid based natural pesticide. Procedia Engineering, 53, 20-28. https://doi.org/10.1016/j.proeng.2013.02.004

Monda, E. O., Munene, S., \& Ndegwa, A. (2003). Snap bean production constraints in Kenya. African Crop Science Conference Proceedings, 6, 683-687.

Mwangi, T. (2013). Threat to market access for kenya's beans and snowpeas to EU. Hortfresh Journal, 5-6. http://hortfreshjournal.com/old/articles/threat_\%20to_Mmarket_access_for\%20kenyas_beans.pdf

Nderitu, J. H., Wambua, E. M., Olubayo, F., Kasina, J. M., \& Waturu, C. N. (2007). Evaluation of snap bean (Phaseolus vulgaris L.) cultivars and breeding lines for resistance to thrips (Thysanoptera: Thripidae) pests in Kenya. Journal of Entomology, 4, 202-208. https://doi.org/10.3923/je.2007.202.209

Nderitu, J., Mwangi, F., Nyamasyo, G., \& Kasina, M. (2009). Evaluation of cropping systems as a strategy for managing snap bean flower thrips in Kenya. International Journal of Sustainable Crop Production, 4(6), $22-25$. 
Ndung'u, A. (2013). Kenya spills the beans. Horticultural News, 2, 36-37.

Soto, A., Ohlenschläeger, F., \& García-marí, F. (2002). Distribution and Sampling of the whiteflies Aleurothrixus floccosus, Dialeurodes citri, and Parabemisia myricae (Homoptera: Aleyrodidae) in citrus in Spain. Journal of Economic Entomology, 95(1), 167-173. https://doi.org/10.1603/0022-0493-95.1.167

United States Agency for International Development-Kenya Horticulture Competitiveness Project (USAID-KHCP) (2011). The European Market for Green Beans Market Survey \#04. United States Agency for International Development-Kenya Horticulture Competitiveness Project Monthly Bulletin.

Vavrina, C. S., Stansly, P. A., \& Liu, T. X. (1995). Household Detergent on Tomato: Phytotoxicity and Toxicity to Silverleaf Whitefly. Hortscience, 30(7), 1406-1409.

\section{Copyrights}

Copyright for this article is retained by the author(s), with first publication rights granted to the journal.

This is an open-access article distributed under the terms and conditions of the Creative Commons Attribution license (http://creativecommons.org/licenses/by/3.0/). 